\title{
Analyzing Abnormal Return Before And After The Announcement Of Merger And Acquisition In 2018
}

\author{
Umi Mardiyati \\ Universitas Negeri Jakarta \\ Email: umi.mardiyati@gmail.com \\ Sonny Haryanto \\ Universitas Negeri Jakarta \\ Email: sonnyharyanto09@gmail.com \\ Agung Dharmawan Buchdadi \\ Universitas Negeri Jakarta \\ Email: agungdharmawan@feunj.ac.id
}

\begin{abstract}
This study aims to analyze the abnormal returns before and after the announcement of mergers and acquisitions in the companies listed on the IDX 2018. In this study, the observation period taken was three days before and after the announcement of mergers and acquisitions with the number of samples observed were 9 companies. The method for calculating abnormal returns used is the market adjusted return by using an intraday stock price of 15 minutes. Based on testing hypotheses conducted by paired sample t-test, it was found that there were no significant differences in abnormal returns before and after the announcement of mergers and acquisitions in each 15 minute period.
\end{abstract}

\footnotetext{
Keywords:

Merger, acquisition, abnormal return, intraday
}

Received: 03 September 2018 ;

Accepted: 20 September 2018;

Publish; October 2018

\section{How to Cite:}

Haryanto, S., Mardiyati, U., Buchdadi, A.. (2018).Analyzing Abnormal Return Before And After The Announcement Of Merger And Acquisition In 2018.Journal of Business and Behavioural Entrepreneurship, 2(1), 9-17.

https://doi.org/10.21009/JOBBE.002.1.02 


\section{INTRODUCTION}

In general, a company in its development experiences various conditions such as dynamic growth and development, static conditions, and bankruptcy conditions (Ramadhariyansyah \& Suwitho, 2013). These conditions are not only influenced by intense competition, but also by other factors such as the economic crisis, deregulation changes, technological progress, and other factors. So, the companies that do not have enough capital will fail to continue their operations and experience bankruptcy, and vice versa. Therefore, companies need to develop and take the right strategies to maintain their existence in order to grow and develop in the long run.

There are various alternatives in preparing the company's strategy to maintain existence, increase efficiency and improve performance in order to become a large company, one of which is to expand. According to Suad and Emy (in As'ari, 2017), expansion is divided into two, namely internal expansion and external expansion. Internal expansion can occur if the division of a company experiences normal growth through capital budgeting. Moreover, external expansion occurs when the company conducts business mergers or acquisitions of other companies.

Acquisition activities in Indonesia have started since the 1970s and are still far compared to developed countries that are more active. The Business Competition Supervisory Commission (KPPU) as a healthy competition monitoring company in Indonesia has data on the announcement of company acquisitions in 2018 from January to April 2018 both companies going public, private in Indonesia as in Table I.

Table 1. Number of Acquisition Announcements in 2018 January - April

\begin{tabular}{|l|l|}
\hline Type of Company & $\begin{array}{l}\text { Number of M\&A } \\
\text { Event }\end{array}$ \\
\hline Non-go-Publik & 15 \\
\hline Go-Publik & 9 \\
\hline Total Source: http://kppu.go.id (2018) \\
\hline \multicolumn{2}{|c|}{ S }
\end{tabular}

Based on the table, the number of announcements of acquisitions in Indonesia in 2018 from January to April amounted to 24 announcements where the number consisted of 15 acquisitions made by private companies and 9 public companies.

The announcement of mergers and acquisitions made by companies can be used by investors as a consideration in investing. This event will affect the reaction of investors to make the right decision. Reactions that occur in the capital market to events such as mergers and acquisitions can be measured using abnormal returns, namely the difference between the actual return and the expected return (Jogiyanto in Astria and Sumiati, 2013). The profit generated from the event is the result of the time and risk that the investor carries out. Then, this study examines the differences in abnormal returns before and after the announcement of mergers and acquisitions.

\section{LITERATURE REVIEW}

\section{Market Efficiency}

Gitman (2012) says Efficient-Market Hypothesis (EMH) is a theory that explains "perfect" market behavior where (1) Securities are in equilibrium, (2) the price of securities fully reflects all available information and reacts quickly to new information, and (3) because the stock shows the price fully and fairly, investors do not need to waste time looking for securities that are undervalued / overvalued.

This concept is important for investment management because it serves as a guide to expectations about profitable trading potential, the possibility of finding investment managers who can beat the market, and the limits of predictability in the capital market (Elton et al, 2014). Based on this concept, investors will always include information factors to make their decisions so that the effects of decision making can be seen from the prices of shares traded.

Fama (in Elad \& Bongbee, 2017) divides market efficiency into three forms, namely Weak Form, describing the state of the capital market where all stock prices are formed from full historical information. Semi Strong Form, describing the state of the capital market where stock prices are not only formed from historical information but also published information. Strong Form, describes the state of the capital market, where the stock price reflects all information including published and private information. 


\begin{abstract}
Signal Theory
Signaling theory is a form of policy carried out by an issuer, government or investor which gives a signal or a sign to the market about the trends or trends to come (Husnan in Astria and Sumiati, 2013). Pratama and Sudhiarta (2014) noted that an announcement can be considered positive if the company manager provides a good corporate perspective to the public in the future.

According to Hartono (in Pratama and Sudhiarta, 2014) a signal can be said to be valid and trustworthy if the company has conditions that are matching to the signals so that it gets a reaction from the parties concerned. These signals can cause positive or negative reactions; positive reactions can occur when a signal has good or beneficial information by interested parties such as investors who want to make benefits of the opportunities to get more profits. Conversely, a negative reaction can occur if a signal is considered to have information that is not good or bad so investors will take action to protect their assets from the risks that can be generated from the information.
\end{abstract}

\title{
Mergers and Acquisitions
}

Merger is a form of absorption of a company against other companies. Most of the cases of mergers are generally large-sized companies that are kept alive and still maintain their name and legal status (surviving firm), while small-scale companies (merged firm) stop activities and their legal status are dissolved.

The acquisition is a form of acquisition of company ownership by the acquirer resulting in a transfer of control/ownership of the company taken over. The control is the power in the form of power to: (1) regulate the financial policies and operations of the company, (2) appoint and terminate management (3) obtain majority voting rights at the board of directors meeting.

\section{Motives of Mergers and Acquisitions}

Every company that conducts mergers and acquisitions has different reasons or motives behind the decision making. According to Moin (2010) the motives of companies to do mergers and acquisitions are Economic Motives, to achieve an increase in the value of the company in the long run by directing activities and decision making to achieve its goals using concrete steps such as through production efficiency, increasing sales, empowering and increasing resource productivity human. Synergy Motives, resulting from the assumption that a combination of simultaneous activities of two or more elements of a company such as operational, financial, managerial, technology and marketing merge so that the activity can produce a greater effect than the company's activities when working separately. Diversification motives, business diversity strategies that are intended to support business activities and company operations to secure competitive positions. Non-economic motives, arise from considerations such as wealth and ambition alone. This motive comes from the personal interests of both the management of the company and the owner of the company.

\section{Previous Research Results}

Research conducted by Astria and Sumiati (2013) shows that there are positive and significant differences in the period before and after that can be seen from the average abnormal return after a higher than before the announcement. This indicates that one of the objectives of the company is to carry out mergers and acquisitions, namely the creation of synergy has been achieved. In addition, from the research of Elad and Bongbee (2017) it was found that there were significant abnormal return changes in the three days leading up to the announcement of mergers and acquisitions which could occur by the possibility of leakage of information or a sign of transactions conducted by "insiders" at the company, which gave they are opportunities for profit. Darlis and Zirman (in Tarigan, 2015) stated that changes in stock prices indicate a change in the level of shareholder prosperity as measured by a positive abnormal return.

Another study conducted by Sundari (2016) also shows that there are differences in abnormal returns before and after mergers and acquisitions. In the research of Shah \& Arora (2016), there is no significant difference in the abnormal return bidder firm. Whereas in target firms results in a significant difference in abnormal returns. This is because investors are aware of the high amount of premium that will be paid to the target company when the negotiations are closed. Thus, this announcement will attract investors to buy target shares in hopes of getting a high return in the future.

Rusnanda and Pardi (2013), show that there is no significant difference between abnormal returns before and after acquisition. These results occur because most likely due to non-economic reasons such as saving other companies from the threat of bankruptcy and personal reasons so that the economic objectives of the company cannot be achieved. Lim and Wiyoto (2015), show that there is no difference between abnormal returns before and after the announcement of mergers and acquisitions.

As'ari (2017), shows that empirically there has been a decrease in abnormal stock returns after the 
announcement of mergers and acquisitions but overall there is no significant difference between abnormal returns before and after the announcement. The absence of these differences is due to information leakage because in general information regarding mergers and acquisitions has entered the agenda of the Company's General Meeting of Shareholders (GMS) so that market response has occurred before the publication is carried out.

Surianto \& Yustiani (2015), shows that there is not enough evidence that there is a significant effect between the announcement before and after the merger and acquisition on abnormal returns. This can occur because of the factors of the global economic crisis which resulted in the absence of market response.

\section{PURPOSES}

Based on the description above as for the purpose of this study is to determine differences in abnormal returns between before and after the announcement of mergers and acquisitions. What distinguishes this research with previous research is the observation period which is carried out 3 days before and 3 days after the announcement of acquisition to prevent other information that can affect, and the stock price used to obtain abnormal returns is to use intraday stock prices every 15 minutes so that the frequency of abnormal return observed are more greater.

The research hypothesis is as follows:

Ho: There is no difference in abnormal returns before and after the announcement of mergers and acquisitions

Ha: There are differences in abnormal returns before and after the announcement of mergers and acquisitions

\section{RESEARCH METHODS}

This study also uses the 7-day event window around the announcement date which is divided into 3 days before $(\mathrm{t}-3)$ and 3 days after $(\mathrm{t}+3)$ while $(\mathrm{t}, 0)$ is the announcement day of mergers and acquisitions. The stock price used in this study is intraday closing price in 15 minutes.

The variable used is abnormal return. Abnormal return calculation in this study uses the market adjusted return model method with the following stages:

Calculating actual stock returns

Actual return is the return that has occurred which is calculated based on the current price relative to the previous price and can be calculated from historical data. According to Elad \& Bongbee (2017) in conducting event studies, sometimes it needs to be seen from its returns and not from the stock price directly. Therefore, the stock price is changed to return natural logarithms. The formula for calculating actual return is as follows:

$$
\boldsymbol{R}_{i t}=\boldsymbol{L N}\left(\boldsymbol{P}_{t} / \boldsymbol{P}_{t-1}\right)
$$

Rit $=$ Actual stock return $\mathrm{i}$ for a period of 15 minutes $\mathrm{t}$

Ln = natural logarithm

$\mathrm{Pt} \quad=$ Price of stock $\mathrm{i}$ for a period of 15 minutes $\mathrm{t}$

Pt-1 = Share price $\mathrm{i}$ before the period of 15 minutes $\mathrm{t}$

Calculating the expected return value

Expected return or E (Rit) is the expected profit if an event does not occur. In the market adjusted return model, the expected return of individual stocks is considered the same as the market return because the formulation on this model assumes that $\alpha=0$ and $\beta=1$. This is based on the assumption that the $\alpha$ value is usually very small while the average $\beta$ of the entire company is close to 1 . In Indonesia to calculate market returns can use Jakarta Composite Index (JCI). Here's the equation for finding market returns:

$$
E\left(R_{i t}\right)=R_{m t}=\frac{J C I_{t}-J C I_{t-1}}{J C I_{t-1}}
$$

$\mathrm{R}_{\mathrm{mt}}=$ Market Return for a period of 15 minutes $\mathrm{t}$

$\mathrm{JCI}_{\mathrm{t}}=$ Jakarta Composite Index for a period of 15 minutes $\mathrm{t}$

$\mathrm{JCI}_{\mathrm{t}-1}=$ Jakarta Composite Index before the 15-minute period $\mathrm{t}$

Calculate abnormal returns

Abnormal returns can be obtained by comparing the expected return with the actual return. Abnor- 
mal return is searched with the following equation:

$$
A R_{i t}=R_{i t}-E\left(R_{i t}\right)
$$

\section{Data collection technique}

This study uses secondary data collection methods as sources. That is the announcement date obtained from the KPPU database (www.kppu.go.id), the data of publicly listed companies listed on the IDX from the www.sahamok.com site and the IDX database (www.idx.co.id), corporate action data obtained from the IDX database (www.idx.co.id), a 15-minute share price obtained from PT. IMQ Multimedia Utama and jsxpro.

The sample in this study was determined using purposive sampling technique, where the sample was chosen based on the criteria that have been determined, (1) the company for each type of industry that conducts mergers \& acquisitions in 2018 (January-April), (2) status public before the merger \& acquisition, (3) do not make other announcements such as dividend announcements (shares, cash, or bonuses) or split stock (observation stock), (4) Completed 15 minutes stock price data. The number of samples taken in this study are 9 companies.

Tabel 3. List of public companies that conduct mergers \& acquisitions used as Sample

\begin{tabular}{|c|c|c|c|c|}
\hline No. & Code & Acquisitor & Target & Date \\
\hline 1 & MASA & PT Multistrada Arah Sarana Tbk & PT Penta Artha Impressi & $01 / 16 / 2018$ \\
\hline 2 & INDY & PT Indika Energy & PT Kideco Kaya Agung & $01 / 19 / 2018$ \\
\hline 3 & ERAA & PT Erajaya Swasembada Tbk & $\begin{array}{l}\text { PT Indonesia Orisinil Teknolo- } \\
\text { gi }\end{array}$ & $02 / 27 / 2018$ \\
\hline 4 & SRIL & PT Sri Rejeki Isman Tbk & $\begin{array}{l}\text { PT. Primayudha Mandirijaya } \\
\text { PT. Bitratex Industries }\end{array}$ & $03 / 26 / 2018$ \\
\hline 5 & KBLI & PT Kmi Wire And Cable Tbk & PT Langgeng Bajapratama & $03 / 29 / 2018$ \\
\hline 6 & ROTI & $\begin{array}{l}\text { PT Nippon Indosari Corporindo } \\
\text { Tbk }\end{array}$ & PT Prima Top Boga & $03 / 29 / 2018$ \\
\hline 7 & ITMG & PT Indo Tambangraya Megah Tbk & PT Energi Batubara Perkasa & $04 / 19 / 2018$ \\
\hline 8 & ICBP & $\begin{array}{l}\text { PT Indofood CBP Sukses Makmur } \\
\text { Tbk }\end{array}$ & $\begin{array}{l}\text { PT Anugerah Indofood Barok- } \\
\text { ah Makmur }\end{array}$ & $04 / 27 / 2018$ \\
\hline 9 & MEDC & PT Medco Energi International & Lundin Indonesia Holding BV & $04 / 27 / 2018$ \\
\hline
\end{tabular}

Source: Kppu.go.id (2018)

\section{Analyzing Technique}

Descriptive statistics, the use of descriptive statistics in this study was conducted to describe the data in the form of mean (mean), maximum, minimum and standard deviation.

Normality, based on the central limit theorem data can be assumed to be normally distributed if the amount of data is more than $30(n>30)$ without regard to population distribution. because the observation data of each sample company uses 15 minutes of data and the number is more than 30 according to the central limit theorem data can be considered normal distribution.

Paired sample t-test is a parametric test to test the difference between two paired samples, namely the before and after abnormal returns. The use of paired sample t-tests was conducted to test hypotheses to analyze whether there were significant differences in abnormal returns before and after the announcement of company mergers and acquisitions. 1) sig (2-tailed) value $<0.05$ can be said there are differences in abnormal returns before and after the announcement of mergers and acquisitions. 2) Sig value. (2-tailed) $>0.05$ it can be said that there are differences in abnormal returns before and after the announcement of mergers and acquisitions.

\section{RESULTS AND DISCUSSION}

\section{Descriptive statistics Results}

Descriptive statistics are used to display an overview of the data samples used in this study. Table 4 presents the abnormal return descriptive statistics before the announcement of the acquisition during the 
observation period which is a 15 -minute period three days before the announcement.

Table 4. Descriptive Statistics Results of Pre-Abnormal Return

\begin{tabular}{lllll}
\hline & Minimum & Maximum & Mean & $\begin{array}{l}\text { Std. Devi- } \\
\text { ation }\end{array}$ \\
\hline MASA & -.05134 & .02155 & -.00022 & .00823 \\
INDY & -.01249 & .02833 & .00018 & .00505 \\
ERAA & -.01495 & .02926 & .00102 & .00778 \\
SRIL & -.01022 & .00690 & -.00026 & .00375 \\
KBLI & -.00999 & .01720 & .00011 & .00467 \\
ROTI & -.01280 & .00873 & .00017 & .00325 \\
ITMG & -.00966 & .01075 & -.00019 & .00390 \\
ICBP & -.00866 & .01368 & .00047 & .00361 \\
MEDC & -.02681 & .01894 & .00001 & .00565 \\
\hline
\end{tabular}

Source: Data processed by Researchers (2018)

From the results of table 4 it can be seen that the standard deviation of all sample companies at the time before the announcement of mergers and acquisitions is more than the average value of abnormal returns. This result indicates the variability of abnormal returns during observation periods are high. In addition, 3 out of 9 companies have an average negative abnormal return consisting of PT. Multistrada Arah Sarana Tbk. $-0.02 \%$, PT. Sri Rejeki Isman Tbk. $-0.026 \%$, and PT. Indo Tambangraya Megah Tbk. $-0.019 \%$. While the other 6 samples have an average abnormal return before a positive announcement. The minimum and maximum columns in the table show the minimum and maximum abnormal return values obtained before the announcement of mergers and acquisitions. Based on the table, the minimum abnormal return value obtained before the merger and acquisition is $-5.13 \%$ by PT. Multistrada Arah Sarana Tbk. while PT. Eraajaya Swasembada is a company that has a maximum abnormal return value of $2.92 \%$.

Table 5. Descriptive Statistics of Post-Abnormal Return

\begin{tabular}{lllll}
\hline & Minimum & Maximum & Mean & Std. Deviation \\
\hline POSTMASA & -.03178 & .06474 & .00074 & .01159 \\
POSTINDY & -.01431 & .01177 & -.00013 & .00442 \\
POSTERAA & -.01150 & .06027 & .00208 & .01094 \\
POSTSRIL & -.01128 & .01880 & .00002 & .00497 \\
POSTKBLI & -.01579 & .02590 & -.00028 & .00564 \\
POSTROTI & -.02840 & .02040 & .00034 & .00694 \\
POSTITMG & -.01382 & .01198 & -.00035 & .00353 \\
POSTICBP & -.02548 & .01434 & .00012 & .00572 \\
POSTMEDC & -.03383 & .03847 & -.00020 & .00757 \\
\hline
\end{tabular}

Source: Data processed by Researchers (2018)

Table 5, shows the results of descriptive statistics of abnormal returns after the announcement of mergers and acquisitions. The results in the table show the standard deviation of all samples that are greater than the mean value which indicates high sample data variability. Other results indicate that 4 sample companies have a negative average abnormal return after the announcement of mergers and acquisitions. In contrast, the other 5 companies have positive average abnormal returns after the announcement of mergers and acquisitions.

* $\quad$ Analyzing Abnormal Return Before And After The Announcement Of Merger And Acquisition In 2018.

* $\quad$ https://doi.org/10.21009/JOBBE.002.1.02 


\begin{tabular}{lllll}
\multicolumn{5}{c}{ Table 6. The Comparison of Cumulative Abnormal return } \\
\hline & PRE & POST & Differ- & \\
\hline MASA & -.01584 & .05237 & 0.06821 & Increase \\
INDY & .01347 & -.00966 & -0.02313 & Decrease \\
ERAA & .07253 & .14736 & 0.07483 & Increase \\
SRIL & -.01859 & .00168 & 0.02027 & Increase \\
KBLI & .00815 & -.02131 & -0.02946 & Decrease \\
ROTI & .01248 & .02561 & 0.01313 & Increase \\
ITMG & -.01462 & -.02491 & -0.01029 & Decrease \\
ICBP & .03514 & .00889 & -0.02625 & Decrease \\
MEDC & .00092 & -.01532 & -0.01624 & Decrease \\
\hline
\end{tabular}

Source: Data processed by Researchers (2018)

In table 6 shows the cumulative abnormal return comparison before and after acquisition acquisition. Cumulative abnormal return increase occurred in 4 research sample companies which are PT. Multistrada Arah Sarana Tbk. (6.82\%), PT. Erajaya Swasembada Tbk. (7.48\%), PT. Sri Rejeki Isman Tbk. (2.03\%), and PT. Nippon Indosari Corpindo Tbk. (1.31\%). The cause of the positive response to the market was due to the acquisition of PT. Indonesia Original Technology (PT. IOT) aims to develop business by registering PT. IOT to obtain information technology-based lending and borrowing service licenses from the Financial Services Authority so as to get good sentiment.

Decrease cumulative abnormal return occurred in 5 companies in this study sample which are namely PT. Indika Energy Tbk. (-2.31\%), PT. KMI Wire and Cable Tbk. (-2.95\%), PT. Indo Tambangraya Megah Tbk. (-1.03\%), PT. Indofood CBP Sukses Makmur Tbk. (-2.63\%), and PT. Medco Energi International Tbk. $(-1.62 \%)$. The biggest cumulative decrease in abnormal return occurred at PT. KMI Wire and Cable Tbk. with the cumulative value of abnormal return of $-2.95 \%$. The decrease was due to the takeover of shares of PT. Langgeng Bajapratama as a supporter of the development plan for the transmission and power generation sector has received a negative response from investors.

\section{Hypothesis test}

This test was carried out using parametric analysis techniques that is paired sample t-test with a significance level of 0.05 .

Table 7. Results of Paired Sample T-test

\begin{tabular}{llll}
\hline & $\mathrm{T}$ & $\begin{array}{l}\text { Sig. (2- } \\
\text { tailed) }\end{array}$ & \\
\hline POSTMASA - PREMA- & .574 & .568 & Insignificant \\
SA & & & Insignificant \\
POSTINDY - PREINDY & -.420 & .676 & Insignificant \\
POSTERAA - PREERAA & .653 & .516 & Insignificant \\
POSTSRIL - PRESRIL & .641 & .524 & Insignificant \\
POSTKBLI - PREKBLI & -.468 & .641 & Insignificant \\
POSTROTI - PREROTI & .188 & .851 & Insignificant. \\
POSTITMG - PREITMG & -.289 & .773 & Insignificant \\
POSTICBP - PREICBP & -.442 & .660 & Insignificant \\
POSTMEDC - PRE- & -.206 & .837 & \\
MEDC & & &
\end{tabular}

Source: Data processed by Researchers (2018)

Based on the paired sample t-test in table 7 sig (2-tailed) value in all company samples, there are MASA of 0.568, INDY 0.676, ERAA 0.516, SRIL 0.524, KBLI 0.641, ROTI 0.851, ITMG 0.773, ICBP 0.660 and MEDC 0.837 shows $>0.05$, which means $h_{a}$ is rejected and $h_{0}$ is accepted. These results indicate that there is not enough evidence that there is a significant difference in abnormal returns in the observation period of this study, that is 3 days before and after the announcement in the 15 -minute period.

* $\quad$ Analyzing Abnormal Return Before And After The Announcement Of Merger And Acquisition In 2018.

* $\quad$ https://doi.org/10.21009/JOBBE.002.1.02 
This result is consistent with research conducted by Rusnanda \& Pardi (2013), As'ari (2017), Lim \& Wiyoto (2015), Surianto \& Triyani (2015) and Shah \& Arora (2014). The insignificant test results prove that although there are abnormal return changes after the announcement of various acquisitions in each company, it has not been proven that there is a statistically significant difference in the response of the market. There may be no response to the market due to several factors, including:(1) Announcement of mergers and acquisitions is not a shocking event or signal and is normal so that market expectations before and after the announcement are not much different, according to As'ari (2017) in general information on mergers and acquisitions is included in the agenda of the General Meeting of Holders Shares (GMS) resulting in information leakage. (2) The global economic crisis, in early January 2018 to mid-year, the rupiah underwent pressure so that the value of the rupiah decreased. This can have an impact on the decision making of investors to resist the desire to invest until the economic situation stabilizes. (3) Lack of active shares traded on the stock exchange. this causes actual return to not change and cause the value to be zero.

The results of this study are not in line with the research conducted by Astria \& Sumiati (2013) and Sundari (2016) which shows that there are differences in abnormal returns before and after the announcement of mergers and acquisitions.

\section{CONCLUSION}

Based on the results of this study, in conclusion there are no abnormal returns before and after mergers and acquisitions. The absence of these differences is caused by a variety of things, namely the market response to mergers and acquisitions as usual so that they do not have expectations that differ significantly between abnormal returns before and after the announcement of mergers and acquisitions, the global economic crisis that causes investors to withhold investment until the economy is stable, and company shares are less actively traded on the stock exchange

\section{Suggestion}

For the next research can (1) use samples of companies that are actively traded on the capital market. (2) adding other variables such as trading volume in 15 minutes so that the results of the research obtained are more varied, (3) Making observations on abnormal returns for each stock trading session.

\section{BIBILIOGRAPHY}

As'ari, L, Amin, M, and Mawardi, M.C. (2017). Analisis Dampak Pengumuman Merger dan Akuisisi Terhadap Abnormal Return Saham Pada Perusahaan Akuisitor yang Terdaftar di BEI Tahun 2013-2015. Jurnal Ilmiah Riset Manajemen, Vol.6, pp.1-11.

Astria, Nike and Sumiati. (2013). Analisis Dampak Pengumuman Merger dan Akuisisi Terhadap Abnormal Return Saham Perusahaan Akuisitor yang Terdaftar di BEI Tahun 2006 - 2008. Jurnal Ilmiah Mahasiswa Universitas Brawijaya, Vol.1, No.2

Elad, F. L. and Bongbee, N. S. (2017). Event Study on the Reaction of Stock Returns to Acquisition News. International Finance and Banking, Vol. 4, No. 1, pp. 33-43

Elton, E. J, Gruber, M. J, Brown, S. J and Goetzman, W. N. (2014). Modern Portofolio Theory and Investment Analysis. United States of America: Wiley

Gitman, L. J and Zutter, C. J. (2012). Principles of Managerial Finance. United States of America: Pearson.

Lim, S.A. and Wiyoto, S. (2014). Analisis Perbedaan Abnormal Return dan Kinerja Keuangan Perusahaan Sebelum dan Sesudah Merger atau Akuisisi. Ultima Accounting, Vol. 6, No. 2, pp. 18-38.

Moin, Abdul. (2010). Merger, Akuisisi dan Divestasi. Jakarta: Ekonisi.

Pratama, I.G.S and Sudhiarta, G.M. 2014. Analisis Perbandingan Abnormal Return Saham Sebelum dan Sesudah Pengumuman Right Issue. E-Jurnal Manajemen Universitas Udayana [S.1.], Vol.3, No.1, pp. 243-257.

Ramadhariyansyah, H and Suwitho. (2013). Dampak Pengumuman Akuisisi Terhadap Abnormal Return Saham Akuisitor Dan Target. Jurnal Ilmu \& Riset Manajemen, Vol. 2, No. 5, pp. 1-20

Rusnanda, E. W and Pardi. (2013). Analisa Pengaruh Pengumuman Merger dan Akuisisi Terhadap Abnormal Return Saham Bank Umum di Bursa Efek Indonesia, Graduasi, Vol.29, pp. 89-101.

Shah, P and Arora. P. (2014). M\&A Announcements and Their Effect on Return to Shareholders: An Event Study, Accounting and Finance Research, Vol. 3, No. 2, pp. 170-190.

Sundari, R. I. (2016). Kinerja Merger dan Akuisisi Pada Perusahaan Go Public. Telaah Bisnis, Vol.17, No.1. pp. 51-64.

Surianto, K and Triyani, Y. (2015). Analisis Merger dan Akuisisi Terhadap Kinerja Keuangan dan Ab- 
Haryanto, S., Mardiyati, U., Buchdadi, A.. (2018).

Journal of Business and Behavioural Entrepreneurship Volume.2 Nomor.1 2018 p (9-17)

normal Return Pada Perusahaan yang Terdaftar di Bursa Efek Indonesia Periode 2009-2012. Jurnal Ekonomi Perusahaan, Vol 22, No. 2, pp.142-159

Tarigan, P. P. and Pratomo, W. A. (2015). Analisis Dampak Merger dan Akuisisi Terhadap Abnormal Return dan Kinerja Keuangan Pada Perusahaan yang Terdaftar di Bursa Efek Indonesia. Jurnal Ekonomi dan Keuangan, Vol.3, No 3, pp. 200-212

* $\quad$ Analyzing Abnormal Return Before And After The Announcement Of Merger And Acquisition In 2018.

* $\quad$ https://doi.org/10.21009/JOBBE.002.1.02 